\title{
Ceiba pentandra, Nigella sativa and their blend as prospective feedstocks for biodiesel
}

\author{
T.M. Yunus Khan a,*, A.E. Atabani b,c,**, Irfan Anjum Badruddin a,***, R.F. Ankalgi ${ }^{\mathrm{d}}$, \\ T.K. Mainuddin Khan ${ }^{\mathrm{d}}$, Ahmad Badarudin ${ }^{\mathrm{a}}$ \\ a Department of Mechanical Engineering, Faculty of Engineering, University of Malaya, 50603 Kuala Lumpur, Malaysia \\ ${ }^{\mathrm{b}}$ Department of Mechanical Engineering, Erciyes University, 38039 Kayseri, Turkey \\ ' Erciyes Teknopark A.Ș, Yeni Mahalle Așikveysel Bulvarı Erciyes Teknopark, Tekno 3 Binası 2, Kat No: 28, 38039 Melikgazi, Kayseri, Turkey \\ d Essar Laboratories and Research Centre, Hubli 580023, Karnataka, India
}

A R T I C L E I N F O

\section{Article history:}

Received 12 June 2014

Received in revised form 1 November 2014

Accepted 7 November 2014

Available online $\mathrm{xxx}$

\section{Keywords:}

Biodiesel feedstocks

Ceiba pentandra

Nigella sativ

Blending

\begin{abstract}
A B S T R A C T
There are more than 350 oil-bearing crops identified as potential sources for biodiesel production around the globe. The wide range of available feedstocks for biodiesel production represents one of the most significant factors for producing biodiesel. The current research work is carried out on fuel properties of biodiesel prepared from the non-edible oils of Ceiba pentandra, Nigella sativa and their mixture. N. sativa is believed to be investigated for the first time as a biodiesel feedstock while C. pentandra has been reported recently in few studies. Owing to higher acid value, acid-esterification and alkali-transesterification processes have been carried out for biodiesel production. The fuel properties of $C$. pentandra methyl ester (CPME), N. sativa methyl ester (NSME) and their feedstock mixture (NSME/CPME) are determined. It has been found that the produced biodiesel from respective feedstocks matches the properties set by ASTM 6751 standards. However, the fuel properties of the C. pentandra biodiesel exhibited better calorific value, viscosity and flash point while $N$. sativa exhibited excellent cold flow properties and oxidation stability.

\section{Introduction}

The fast depletion and rising prices of crude petroleum products besides their harmful emission are the main concerns to search for alternative fuels from renewable sources (Reyes-Trejo et al., 2014). Globally transportation sector is the second largest sector after industrial sector which consumes more oil (Perez-Lombard et al., 2008; Rashid et al., 2013). The transportation is the fundamental requirement for any society for its overall development and improvement (He et al., 2005). Biodiesel has emerged as an alternative fuel for internal combustion engines because of its renewability and environmental friendly nature (Amani et al., 2013). Apart from these advantages biodiesel can be used in the existing diesel engine without any further modifications (Canakci, 2007; Gerpen, 2005). The feedstocks for biodiesel can be broadly divided into three

\footnotetext{
* Corresponding author. Tel.: +60 0173960784.

** Corresponding author at: Department of Mechanical Engineering, Erciyes Uni-

versity, 38039 Kayseri, Turkey. Tel.: +90 5366063795.
$* * *$ Corresponding author. Tel.: +60 0379674463 ; fax: +60 0379675317.

E-mail addresses: yunus.tatagar@gmail.com (T.M. Yunus Khan),

a_atabani2@msn.com (A.E. Atabani), irfan_magami@rediffmail.com(I.A. Badruddin).

http://dx.doi.org/10.1016/j.indcrop.2014.11.013

0926-6690/@ 2014 Elsevier B.V. All rights reserved.
}

categories, i.e. vegetable oils (edible and non-edible), animal fats and waste cooking oils (Karmakar et al., 2010). However, the attention is primarily focused toward biodiesel from non-edible feedstocks due to the food-fuel crisis and land availability problems (Yunus Khan et al., 2014; Atabani et al., 2013a; Bouriazos et al., 2014; Chen et al., 2013; Elsheikh, 2013). Furthermore, the production of biodiesel from non-edible feedstocks reduces the cost of biodiesel significantly compared to edible feedstocks (Atabani et al., 2013b).

Ceiba pentandra, a non-edible and draught resistant plant which is commonly known as kapok fiber has attracted some researchers (Sivakumar et al., 2013; Tye et al., 2012). It belongs to Malvaceae family and native of Southeast Asia, India and Sri Lanka (Rahmah and Abdullah, 2011). The seeds of $C$. pentandra are brownish black in color and occupy $25-28 \%$ by weight for each fruit with an average oil yield of $1280 \mathrm{~kg} / \mathrm{ha}$ annually. It has been recommended as a suitable feedstock for biodiesel production (Silitonga et al., 2013). Furthermore, C. pentandra,Sterculia foetida and Jatropha curcas have been compared for their fuel properties. It has been pointed out that all three oils are suitable for biodiesel production (Ong et al., 2013).

Nigella sativa is commonly known as black seeds or black cumin which belongs to the botanical family of Ranunculaceae with more than $35 \%$ oil content. It is native to south and southwest Asia but also 


Nomenclature
CCPO crude Ceiba pentandra oil
CCPO + CNSO mixture of crude oils of Ceiba pentandra and
Nigella sativa
CNSO crude Nigella sativa oil
CPME Ceiba pentandra methyl ester
NSME Nigella sativa methyl ester
NSME + CPME methyl esters from mixture of crude oils of
Ceiba pentandra and Nigella sativa

cultivated in different parts of the world. $N$. sativa found to be suitable feedstock for biodiesel with $93 \%$ conversion with satisfactory yields (85.6-97.7\%) (Aghabarari et al., 2014). Fig. 1 shows the two potential non-edible feedstocks for biodiesel production. However, it is believed that there is no paper which gives the details of fuel properties of $N$. sativa biodiesel and compares it with C. pentandr biodiesel.

In this paper, an attempt has been made to investigate and analyze further about fuel properties of $\mathrm{C}$. pentandra biodiesel. In addition to this suitability of $N$. sativa methyl esters as biodiesel, comparison of fuel properties of C. pentandra, $N$. sativa and their different blends with diesel has been carried out.

It is reported that the feedstock blends could improve the fuel properties (Sanjid et al., 2014). Therefore, the fuel properties of biodiesel produced from the blend of both crude oils of $C$. pentandr and $N$. sativa have been investigated and analyzed.

\section{Materials and methods}

\subsection{Materials}

The crude oil of C. pentandra (Kapok) was purchased from Java, Indonesia while the crude oil of $N$. sativa (Black cumin) was purchased from Bangladesh through personal communications. The chemicals required for the chemical reactions such as methanol, sulfuric acid, hydrochloric acid, potassium hydroxide, sodium sulphate etc. were purchased from the local market of Kuala Lumpur. Malaysia.
Table 1

Summary of biodiesel production from CCPO, CNSO and CCPO + CNSO.

\begin{tabular}{lll}
\hline No. & Process parameter & Process specification \\
\hline 1 & Process selected & Acid-base catalyst \\
& process \\
2 & Reaction temperature & $60^{\circ} \mathrm{C}$ \\
& & $98 \%$ sulfuric acid $(1 \%$, \\
& $\mathrm{v} / \mathrm{v})$ for CCPO \\
3 & $37 \%$ hydrochloric acid \\
& $(1 \%, \mathrm{v} / \mathrm{v})$ for CNSO and \\
& Catalyst used & CCPO + CNSO $\& 99 \%$ \\
& & pure potassium \\
& & hydroxides $(1 \%, \mathrm{~m} / \mathrm{m})$ \\
& & Methanol: crude oil \\
4 & Alcohol used & $(1: 2, \mathrm{v} / \mathrm{v})$ for \\
& & esterification \\
& & Methanol: crude oil \\
& & $(1: 4, \mathrm{v} / \mathrm{v})$ for \\
& & transesterification \\
& & $3 \mathrm{~h}$ for esterification \\
5 & Reaction time & $2 \mathrm{~h}$ for \\
& & transesterification \\
& & 700 rpm \\
\hline
\end{tabular}

\subsection{Biodiesel production method}

Biodiesel was produced from the crude oil by chemical reactions known as esterification and transesterification. The transesterification method is used to reduce the viscosity of crude oils by converting them into methyl esters (Thomas et al., 2012). It is regarded as the best method compared to others due to its simplicity and lower cost of production (Atabani et al., 2012). However, employment of esterification reaction depends on the acid value of respective crude oils. In this paper the crude oils of $C$. pentandra; $N$. sativa and their blend have higher acid values, determined by the titration of respective oils with the standardized base solution. Hence, the two step esterification and transesterification catalyzed reactions were employed for biodiesel production. The biodiesel from the above crude oils were produced in the laboratory using $1 \mathrm{~L}$ batch reactor. The summary of the production processes are given in Table 1.

\subsubsection{Biodiesel production from C. pentandra and N. sativa oils}

Acid catalysis or the esterification is basically applied when the acid value of the crude oil is higher. In this study we found that

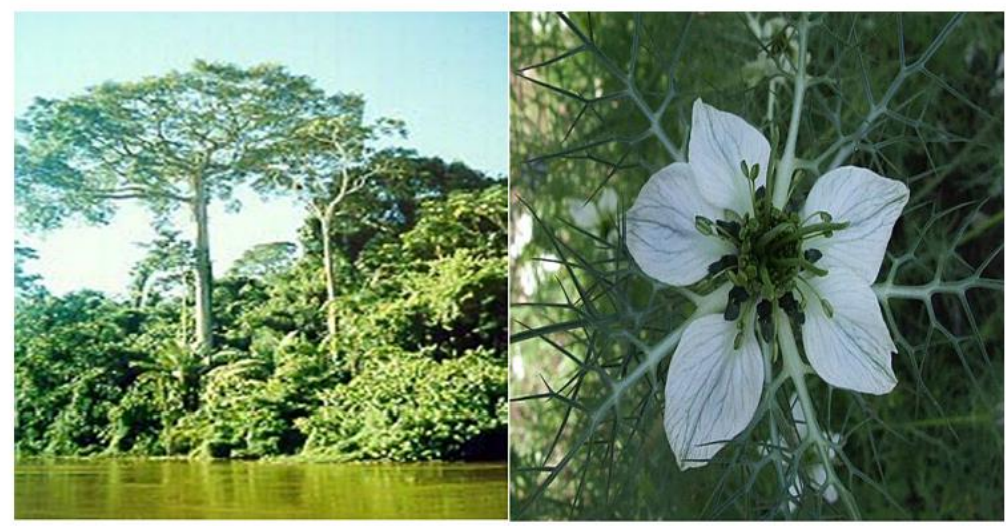

Kapok Tree

Nigella sativa plant

Fig. 1. Nonedible feedstocks of Ceiba pentandra and Nigella sativa.

Please cite this article in press as: Yunus Khan, T.M., et al., Ceiba pentandra, Nigella sativa and their blend as prospective feedstocks for biodiesel. Ind. Crops Prod. (2014), http://dx.doi.org/10.1016/j.indcrop.2014.11.013 
Table 2

\begin{tabular}{llllll} 
Equipment list. \\
\hline No & Property & Equipment & Manufacturer & ASTM D6751 & ASTM D6751 limit \\
\hline 1 & Kinematic viscosity & SVM 3000 automatic & (Anton Paar, UK) & D 445 & $1.9-6.0$ \\
2 & Flash point & Pensky-martens flash point automatic NPM 440 & (Normalab, France) & D 93 & 130 min \\
3 & Oxidation stability & 873 Rancimat - automatic & (Metrohm, Switzerland) & D 675 & $3 \mathrm{hmin}$ \\
4 & Cloud and pour point & Cloud and Pour point tester - automatic NTE 450 & (Normalab, France) & D 2500 and D 97 & Report \\
5 & CFPP & Cold filter plugging point - automatic NTL 450 & (Normalab, France) & D 6371 & N/S \\
6 & Density & SVM 3000 - automatic & (Anton Paar, UK) & D 1298 & N/S \\
7 & Dynamic viscosity & SVM 3000 - automatic & (Anton Paar, UK) & N/S & N/S \\
8 & Viscosity index (VI) & SVM 3000- automatic & (Anton Paar, UK) & N/S & N/S \\
9 & Caloric value & C2000 basic calorimeter - automatic & (IKA, UK) & & N/S \\
\hline
\end{tabular}

the acid value of both the crude oils is high hence, initially both the crude oils were esterified or acid catalyzed. In esterification process the crude oil was mixed with methanol in the ratio of $2: 1$ by volume. $98 \%$ concentrated sulphuric acid ( $1 \% \mathrm{v} / \mathrm{v}$ oil) was added to the mixture of crude oil and methanol. In this study sulphuric acid was used as a catalyst in the production of biodiesel from $C$. pentandra. However, $37 \%$ concentrated hydrochloric acid $(1 \%, v / v$, oil) was used in the production of the biodiesel from $N$. sativa owing to its higher acid value compared with its counterpart C. pentandra oil (Su, 2013). The mixture of crude oil, methanol and the respective catalysts were refluxed with constant boiling in the reactor at $60^{\circ} \mathrm{C}$ for $3 \mathrm{~h}$ under the stirrer speed of $700 \mathrm{rpm}$ approximately.

After $3 \mathrm{~h}$, the reaction was stopped. The mixture obtained had two layers, the upper layer of methanol and acid and the lower layer that of esterified oil. The esterified oil was separated from the methanol and other impurities with the help of separating funnel. The esterified oil was put into the rotary evaporator to remove the traces of moisture contents and excess alcohol. The rotary evaporator surrounded by distilled water was maintained at a temperature of $50-60{ }^{\circ} \mathrm{C}$. The pure esterified oil was collected and made ready for the transesterification process.

The alkaline catalysis or transesterification process had similar reaction conditions as that of esterification. In this process the esterified oil was mixed with methanol in the ratio of $4: 1$ by volume in the reactor. The mixture was added with $1 \%$ of potassium hydroxide by weight. The reaction was maintained at a temperature of $60^{\circ} \mathrm{C}$ and stirrer speed of $700 \mathrm{rpm}$ for $2 \mathrm{~h}$.

After $2 \mathrm{~h}$ of the reaction, the upper layer of the biodiesel was separated from the lower layer of methanol including other impurities, with the help of separating funnel. This was followed by the post treatment processes. The transesterified oil was washed repeatedly by hot $\left(60^{\circ} \mathrm{C}\right)$ distilled water. The clean biodiesel was then put into the rotary evaporator and the same procedure was applied to evaporate the moisture and excess methanol from the biodiesel as applied before for esterified oil.

Finally, the biodiesel was further cleaned with sodium sulphate and filtered with a filter paper to get the biodiesel with negligible impurities.

\subsubsection{Biodiesel from mixture of $C$. pentandra and $N$. sativa crude}

oils

The production of biodiesel from respective feedstock mixture was carried out. In this case, both the crude oils viz. C. pentandra and $N$. sativa were mixed in equal proportion by volume. Here also the mixture had higher acid value. Hence, it was decided to go for esterification and transesterification of the blended crude oils. The reaction conditions and procedures were same as applied before for their individual oils. However, the esterification process was carried out with $37 \%$ concentrated hydrochloric acid. The post treatment and filtering procedures too remained same as stated before.

\subsection{Equipment list and properties for analysis}

In this study the physicochemical properties of crude oils of $C$ pentandra, $N$. sativa, mixture of $C$. pentandra and $N$. sativa including their respective methyl esters and blends have been studied in accordance with the ASTM D6751 standards (Mofijur et al., 2013). Table 2 shows the list of equipment used for the investigation of the properties.

\subsection{Biodiesel-diesel blending}

The fuels to be tested were blended with diesel in different ratios using a homogenizer device at a speed of $2000 \mathrm{rpm}$. Homogenizer was fixed on a clamp on a vertical stand, which allows changing of the homogenizer's height. The two fuels, i.e. biodiesel and diesel were mixed in proper ratios by turning on the plug of the homogenizer. In this study, $10 \%, 20 \%, 40 \%, 60 \%$ and $80 \%$ biodiesel were blended with the respective quantity of diesel. Hence, $10 \%$ biodiesel and $90 \%$ diesel by volume was assigned as B10. Similarly others were labeled as B20, B40, B60 and B80 respectively.

\section{Results and discussion}

\subsection{Fatty acid composition of biodiesel}

The free fatty acid composition of the biodiesel is shown in Table 3. It can be seen that the main constituents are palmitic acid, oleic acid and linoleic acid. Biodiesel from $N$. sativa possesses the highest contents of linoleic and oleic acids (43.1\% and 25.8\%) followed by the mixture of feedstocks $(41.0 \%$ and $23.2 \%$ ) and C. pentandra (38.1\% and 20.1\%), while C. pentandra biodiesel possesses the highest contents of palmitic acid (20.8\%) followed by the mixture of feedstock (15.3\%) and N. sativa (10.2\%).

Table 3

The fatty acid composition of different biodiesel.

\begin{tabular}{llrrr}
\hline Fatty acid name & Structure & NSME & CPME & CPME + NSME \\
\hline Caprylic & C8:0 & $<0.1$ & $<0.1$ & $<0.1$ \\
Capric & C10:0 & $<0.1$ & $<0.1$ & $<0.1$ \\
Lauric & C12:0 & $<0.1$ & $<0.1$ & $<0.1$ \\
Myristic & C14:0 & 0.1 & 0.1 & 0.1 \\
Palmitic & C16:0 & 10.2 & 20.8 & 15.3 \\
Palmitoleic & C16:1 & 0.2 & 0.3 & 0.3 \\
Margaric & C17:0 & 0.1 & 0.1 & 0.1 \\
Stearic & C18:0 & 3.7 & 2.7 & 3.1 \\
Oleic & C18:1 & 25.8 & 20.1 & 23.2 \\
Linoleic & C18:2 & 43.1 & 38.1 & 41.0 \\
C18:2 isomer & C18:2 isomer & $<0.1$ & 3.5 & 1.2 \\
Linolenic & C18:3 & 1.4 & 1.7 & 1.6 \\
Arachidic & C20:0 & 0.6 & 0.5 & 0.6 \\
Gondoic & C20:1 & 1.4 & 0.1 & 0.8 \\
C20:0 isomer & C20:0 isomer & 1.5 & 1.1 & 0.8 \\
Behenic & C22:0 & 0.6 & 0.4 & 0.5 \\
Erucic & C22:1 & 9.0 & 0.1 & 4.5 \\
Lignoceric & C24:0 & 0.3 & 0.1 & 0.3 \\
\hline
\end{tabular}


Table 4

The properties of crude oils and their respective methyl esters (biodiesel).

\begin{tabular}{|c|c|c|c|c|c|c|}
\hline Property & CCPO & CPME & CNSO & NSME & $\mathrm{CCPO}+\mathrm{CNSO}$ & $\mathrm{NSME}+\mathrm{CPME}$ \\
\hline Calorific value (kJ/kg) & 39,498 & 40,064 & 39,251 & 39,967 & 39,372 & 39,945 \\
\hline Kinematic viscosity $\left(\mathrm{mm}^{2} / \mathrm{s}\right)$ at $40^{\circ} \mathrm{C}$ & 34.592 & 4.4180 & 32.3680 & 4.5026 & 33.375 & 4.4421 \\
\hline Dynamic viscosity (mPa.s) at $40^{\circ} \mathrm{C}$ & 31.286 & 3.8264 & 29.3880 & 3.9067 & 30.243 & 3.8509 \\
\hline Density $\left(\mathrm{kg} / \mathrm{m}^{3}\right)$ at $15^{\circ} \mathrm{C}$ & 0.9216 & 0.8844 & 0.9247 & 0.8861 & 0.9230 & 0.8848 \\
\hline Specific gravity at $15^{\circ} \mathrm{C}$ & 0.9224 & 0.8852 & 0.9255 & 0.8869 & 0.9238 & 0.8856 \\
\hline Density $\left(\mathrm{kg} / \mathrm{m}^{3}\right)$ at $40^{\circ} \mathrm{C}$ & 0.9044 & 0.8661 & 0.9079 & 0.8677 & 0.9062 & 0.8669 \\
\hline Kinematic viscosity at $100^{\circ} \mathrm{C}$ & 7.6958 & 1.7260 & 7.1132 & 1.7457 & 7.3935 & 1.7527 \\
\hline Pour point $\left({ }^{\circ} \mathrm{C}\right)$ & -3 & 5 & -7 & -1 & -2 & -1 \\
\hline CFPP $\left({ }^{\circ} \mathrm{C}\right)$ & 44 & 4 & 29 & -4 & 32 & -1 \\
\hline Viscosity index (VI) & 201.6 & 216.5 & 191.6 & 232.6 & 197.4 & 231.6 \\
\hline
\end{tabular}

3.2. Characterization of crude oils and their methyl esters

The different properties of crude oils along with their respective methyl esters have represented in Table 4. The main findings of this table indicate that $N$. sativa has $(39,251 \mathrm{~kJ} / \mathrm{kg})$ comparatively lower calorific value than C. pentandra $(39,498 \mathrm{~kJ} / \mathrm{kg})$ and the feedstock mixture $(39,372 \mathrm{~kJ} / \mathrm{kg})$. However, they have marginal difference in calorific value in terms of their respective methyl esters. Kinematic viscosity of C. pentandra methyl ester is $\left(4.4180 \mathrm{~mm}^{2} / \mathrm{s}\right.$ ) better compared to other methyl esters though its crude oil has highest viscosity than other two. The cold flow properties of $N$ sativa methyl ester seem to be better than other two types of methyl esters. After observing the different properties of the methyl esters of C. pentandra and N. sativa, it can be concluded that these two biodiesel have some advantages as well as limitations as far as fuel properties are concerned. However, the methyl ester from the feedstock mixture possesses excellent properties including the calorific value, viscosity, cold flow properties, oxidation stability, etc.

\subsection{Physical and chemical properties of biodiesel with their respective blends}

Biodiesel is seen as the most acceptable alternative fuel for diesel engines with little or no modifications on the engines apart from its technical and environmental benefits. In addition to this, they are completely soluble in petroleum diesel. However, differences in the chemical structure of biodiesel and diesel fuel make a difference in the basic properties of biodiesel blend such as viscosity, calorific value, flash point, cloud and pour point etc. which further affect the engine performance and emission (Benjumea et al. 2008). The fuel properties of biodiesel, either physical or chemical are strongly influenced by the properties of their respective fatty
Calorific value $\mathrm{kJ} / \mathrm{kg}$ v/s blends

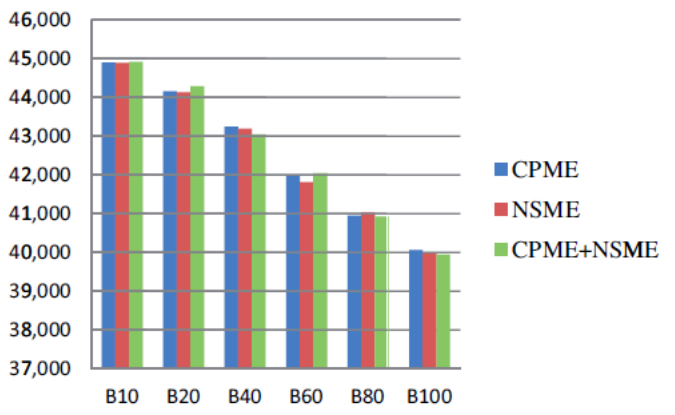

Fig. 2. Calorific value of different biodiesel with different blends.

esters in biodiesel (Knothe, 2005). Hence, it is important to know the basic properties of the biodiesel before using them into engines as fuel. Tables 5-7 show the detailed properties of blends of diesel and methyl esters produced from C. pentandra, N. sativa and mixture of $C$. pentandra and $N$. sativa feedstocks respectively.

\subsubsection{Calorific value}

The calorific value is generally termed as the energy content or the energy per unit mass of the fuel. The calorific value of biodiesel is lower compared to diesel due to the presence of higher oxygen contents (Atabani et al., 2013a).

Fig. 2 shows the variation of calorific value with the variation in blends. Obviously, diesel (B0) possesses the highest calorific value as compared to biodiesel. The observation on the biodiesel shows

Table 5

The properties of Ceiba pentandra methyl ester and its blends.

\begin{tabular}{|c|c|c|c|c|c|c|}
\hline Property & B0 & B10 & B20 & B40 & B 60 & B80 \\
\hline Calorific value $(\mathrm{kJ} / \mathrm{kg})$ & 45,369 & 44,900 & 44,155 & 43,245 & 42,007 & 40,952 \\
\hline Kinematic viscosity $\left(\mathrm{mm}^{2} / \mathrm{s}\right)$ at $40^{\circ} \mathrm{C}$ & 3.6056 & 3.6572 & 3.7089 & 3.8594 & 4.0245 & 4.225 \\
\hline Dynamic viscosity (mPas) at $40^{\circ} \mathrm{C}$ & 3.0095 & 3.0634 & 3.1183 & 3.2688 & 3.435 & 3.6338 \\
\hline Density $\left(\mathrm{kg} / \mathrm{m}^{3}\right)$ at $15^{\circ} \mathrm{C}$ & 0.8518 & 0.8553 & 0.8579 & 0.8645 & 0.8712 & 0.8780 \\
\hline Specific gravity at $15^{\circ} \mathrm{C}$ & 0.8526 & 0.8561 & 0.8587 & 0.8653 & 0.872 & 0.8788 \\
\hline Density $\left(\mathrm{kg} / \mathrm{m}^{3}\right)$ at $40^{\circ} \mathrm{C}$ & 0.8347 & 0.8376 & 0.8408 & 0.847 & 0.8535 & 0.8601 \\
\hline Kinematic viscosity at $100^{\circ} \mathrm{C}$ & 1.3845 & 1.4043 & 1.4333 & 1.4988 & 1.5716 & $1.651 \mathrm{~s}$ \\
\hline Pour point $\left({ }^{\circ} \mathrm{C}\right)$ & 2 & 2 & 3 & 3 & 0 & 3 \\
\hline $\operatorname{CFPP}\left({ }^{\circ} \mathrm{C}\right)$ & 0 & 5 & 4 & 3 & 3 & 0 \\
\hline Viscosity index (VI) & 120.3 & 129.5 & 145 & 166.4 & 189.1 & 204.7 \\
\hline
\end{tabular}

$\mathrm{N} / \mathrm{R}=$ not required.

Please cite this article in press as: Yunus Khan, T.M., et al., Ceiba pentandra, Nigella sativa and their blend as prospective feedstocks for biodiesel. Ind. Crops Prod. (2014), http://dx.doi.org/10.1016/j.indcrop.2014.11.013 
Table 6

The properties of Nigella sativa methyl ester and its blends.

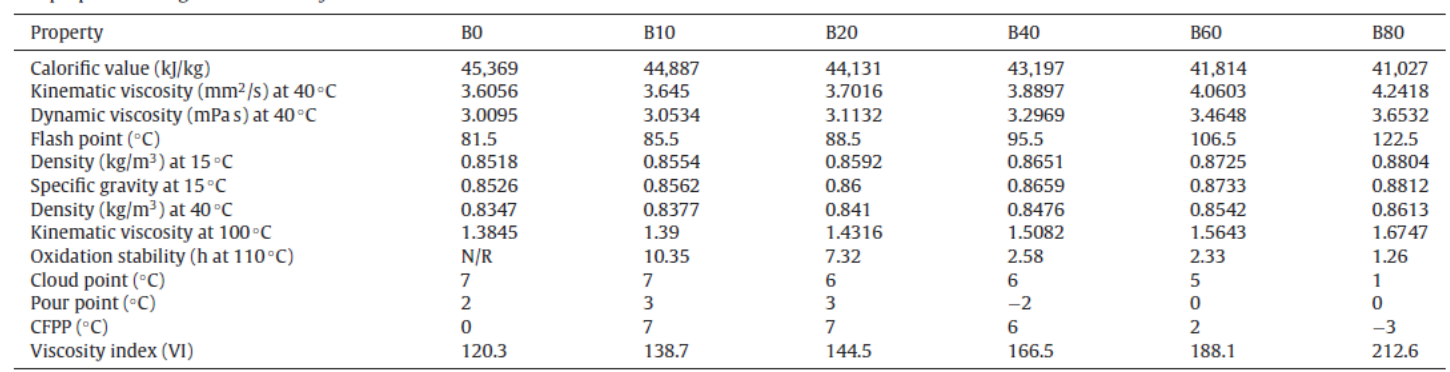

$\mathrm{N} / \mathrm{R}=$ not required

Table 7

The properties of methyl ester from the feedstock mixture (NSME/CPME) and its blends.

\begin{tabular}{|c|c|c|c|c|c|c|}
\hline Property & Bo & B10 & B20 & B40 & B60 & B80 \\
\hline Calorific value (kJ/kg) & 45,369 & 44,921 & 44,283 & 43,046 & 42,041 & 40,923 \\
\hline Kinematic viscosity $\left(\mathrm{mm}^{2} / \mathrm{s}\right)$ at $40^{\circ} \mathrm{C}$ & 3.6056 & 3.7038 & 3.753 & 3.8615 & 4.0256 & 4.2441 \\
\hline Dynamic viscosity (mPas) at $40^{\circ} \mathrm{C}$ & 3.0095 & 3.1054 & 3.1586 & 3.2733 & 3.4386 & 3.6540 \\
\hline Flash point $\left({ }^{\circ} \mathrm{C}\right)$ & 81.5 & 87.5 & 90.5 & 97.5 & 106.5 & 124.5 \\
\hline Density $\left(\mathrm{kg} / \mathrm{m}^{3}\right)$ at $15^{\circ} \mathrm{C}$ & 0.8518 & 0.856 & 0.8588 & 0.865 & 0.8718 & 0.8791 \\
\hline Specific gravity at $15^{\circ} \mathrm{C}$ & 0.8526 & 0.8568 & 0.8596 & 0.8658 & 0.8726 & 0.8799 \\
\hline Density $\left(\mathrm{kg} / \mathrm{m}^{3}\right)$ at $40^{\circ} \mathrm{C}$ & 0.8347 & 0.8384 & 0.8416 & 0.8477 & 0.8542 & 0.861 \\
\hline Kinematic viscosity at $100^{\circ} \mathrm{C}$ & 1.3845 & 1.4205 & 1.4446 & 1.5 & 1.5735 & 1.6605 \\
\hline Oxidation stability (h at $110^{\circ} \mathrm{C}$ ) & $N / R$ & 15.12 & 7.53 & 3.16 & 1.41 & 1.03 \\
\hline Cloud point $\left({ }^{\circ} \mathrm{C}\right)$ & 7 & 7 & 7 & 5 & 4 & 1 \\
\hline Pour point $\left({ }^{\circ} \mathrm{C}\right)$ & 2 & 2 & 2 & 5 & 2 & -1 \\
\hline $\operatorname{CFPP}\left({ }^{\circ} \mathrm{C}\right)$ & 0 & 5 & 5 & 3 & 2 & -2 \\
\hline Viscosity index (VI) & 120.3 & 128.6 & 143.1 & 168.6 & 190.2 & 207.3 \\
\hline
\end{tabular}

$\mathrm{N} / \mathrm{R}=$ not required

that there is a marginal difference in the calorific value of $C$. pentandra and N. sativa. However, especially B10 and B20 blends from the mixture of feedstocks (CPME + NSME) give slightly higher calorific value of $44,921 \mathrm{~kJ} / \mathrm{kg}$ and $44,283 \mathrm{~kJ} / \mathrm{kg}$ than their respective individual methyl ester blends (CPME (B10 and B20) and NSME (B10 and B20)), i.e. $44,900 \mathrm{~kJ} / \mathrm{kg}, 44,155 \mathrm{~kJ} / \mathrm{kg}$ and $44,887 \mathrm{~kJ} / \mathrm{kg}, 44,131 \mathrm{~kJ} / \mathrm{kg}$ respectively.

\subsubsection{Kinematic viscosity}

Kinematic viscosity is another important property of any fuel, because high viscosity could cause excessive fuel injection pressure during engine warm-up (Tat and van Gerpen, 1999). Though the viscosity of biodiesel is higher than the petro diesel (Knothe and Steidley, 2007), but still it can be observed that all the methyl esters and their blends have acceptable viscosities according to the limit specified by ASTM D6751 of $\left(1.9-6 \mathrm{~mm}^{2} / \mathrm{s}\right)$.

From Fig. 3, it is evident that the viscosity increases with the quantity of biodiesel in the blend. However, for B10 and B20 in contrast to calorific value, viscosity of $N$. sativa $\left(3.6056 \mathrm{~mm}^{2} / \mathrm{s}\right.$ and $3.645 \mathrm{~mm}^{2} / \mathrm{s}$ ) is comparatively better than the other two esters. Furthermore, as the quantity of biodiesel was increased, it was found that $C$. pentandra $\left(4.0245 \mathrm{~mm}^{2} / \mathrm{s}\right)$ and the methyl ester from the mixture $\left(4.0256 \mathrm{~mm}^{2} / \mathrm{s}\right)$ possessed slightly better viscosity than N. sativa $\left(4.0603 \mathrm{~mm}^{2} / \mathrm{s}\right)$.

\subsubsection{Flash point}

The flash point of any fuel is the lowest temperature at which it possesses enough vapors to ignite in the presence of a source of ignition. It is the important parameter as far as storage and handling issues are concerned (Elliott, 2013).

The flash point of $C$. pentandra is more for almost all of its blends than the N. sativa and the feed stock mixture methyl ester.

Please cite this article in press as: Yunus Khan, T.M., et al., Ceiba pentandra, Nigella sativa and their blend as prospective feedstocks for biodiesel. Ind. Crops Prod. (2014), http://dx.doi.org/10.1016/j.indcrop.2014.11.013
Especially for $\mathrm{B} 100$, it is $\left(202.5^{\circ} \mathrm{C}\right)$ which is much more than the flash point of $N$. sativa $\left(172.5^{\circ} \mathrm{C}\right)$. However, the mixture gives the flash point of $186.5^{\circ} \mathrm{C}$ which is in between the values obtained by other two methyl esters. Fig. 4 shows the variation of flash point with the blends. It is noting worth that the flash point of all the biodiesel are within the limit set by ASTM D6751 of minimum of $130^{\circ} \mathrm{C}$.

\subsubsection{Oxidation stability}

Oxidation stability is one of the important biodiesel quality parameters. The auto oxidation process of the fuel during its storage makes the fuel unsuitable to be used in engines (Sendzikiene et al., 2005). ASTM D6751standard specifies a minimum of $3 \mathrm{~h}$ of the induction period for the oxidation stability.

The oxidation stability of the different blends illustrates some interesting results as shown in Fig. 5. Except for B80 and B60 the

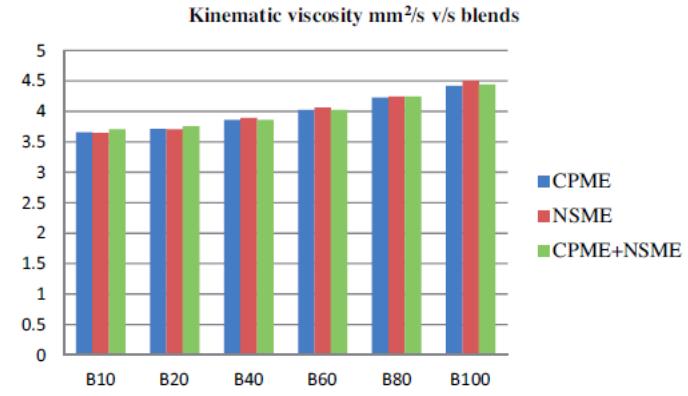

Fig. 3. Kinematic viscosity of different biodiesel with different blends.

Link to Full-Text Articles :

http://www.sciencedirect.com/science/article/pii/S0926669014007006 